\title{
Decreased salivation to food cues in formerly obese successful dieters
}

Citation for published version (APA):

Jansen, A. T. M., Stegerman, S., Roefs, A. J., Nederkoorn, C., \& Havermans, R. C. (2010). Decreased salivation to food cues in formerly obese successful dieters. Psychotherapy and Psychosomatics, 79(4), 257-258. https://doi.org/10.1159/000315131

Document status and date:

Published: 01/01/2010

DOI:

10.1159/000315131

Document Version:

Publisher's PDF, also known as Version of record

Document license:

Taverne

Please check the document version of this publication:

- A submitted manuscript is the version of the article upon submission and before peer-review. There can be important differences between the submitted version and the official published version of record.

People interested in the research are advised to contact the author for the final version of the publication, or visit the DOI to the publisher's website.

- The final author version and the galley proof are versions of the publication after peer review.

- The final published version features the final layout of the paper including the volume, issue and page numbers.

Link to publication

\footnotetext{
General rights rights.

- You may freely distribute the URL identifying the publication in the public portal. please follow below link for the End User Agreement:

www.umlib.nl/taverne-license

Take down policy

If you believe that this document breaches copyright please contact us at:

repository@maastrichtuniversity.nl

providing details and we will investigate your claim.
}

Copyright and moral rights for the publications made accessible in the public portal are retained by the authors and/or other copyright owners and it is a condition of accessing publications that users recognise and abide by the legal requirements associated with these

- Users may download and print one copy of any publication from the public portal for the purpose of private study or research.

- You may not further distribute the material or use it for any profit-making activity or commercial gain

If the publication is distributed under the terms of Article $25 \mathrm{fa}$ of the Dutch Copyright Act, indicated by the "Taverne" license above, 
Psychother Psychosom 2010;79:257-258

DOI: $10.1159 / 000315131$

\section{Decreased Salivation to Food Cues in Formerly Obese Successful Dieters}

Anita Jansen, Sophie Stegerman, Anne Roefs, Chantal Nederkoorn, Remco Havermans

Department of Clinical Psychological Science, Faculty of Psychology and Neuroscience, Maastricht University, Maastricht, The Netherlands

Obesity is a major health problem that has been increasing dramatically worldwide. To reduce its health threats and costs, weight loss is necessary. However, weight loss and in particular its maintenance is difficult. It is estimated that merely $20 \%$ of the obese are able to reduce to a normal weight and to maintain it for at least a year [1]. One of the key strategies related to successful weight loss is great diet commitment and strict, regular and consistent dieting, that is, maintaining the same diet regimen across the day, week and year [1]. It is, however, not clear why some people are better able to stick to their diet than others in the current context of a 'toxic' environment in which highly palatable energydense foods are widely available and the need for physical activity is decreased. A difference between successful and unsuccessful dieters might be related to the automatic responding of one's body to appetitive cues. Overeating is associated with increased cue reactivity, that is, increased appetitive responding to food cues [2]. When overeaters are confronted with a diverse range of tasty food cues that are predictive of food intake - like the smell, taste and sight of high-calorie foods - they show increased cephalic phase responding, like salivation and the release of insulin, followed by increased food intake $[2,3]$. As a consequence, dieting is much easier without these appetitive responses. Appetitive responding extinguishes when exposure to foods systematically remains unreinforced [2], thereby assuming that strict dieting will lead to an extinction of appetitive responses. Knowing that successful dieters are strict, whereas unsuccessful dieters are less so [1], it was hypothesized that formerly obese successful dieters (FOSD) show decreased salivary responding during exposure to tasty high-fat food cues, whereas currently obese unsuccessful dieters (COUD) show increased salivary responding during exposure to tasty high-fat food cues.

The participants were 11 FOSD and 12 COUD. The FOSD participants were currently at normal weight $(\mathrm{BMI} \leq 25)$ after an intentional weight loss of $\geq 10 \%$ and a successful maintenance of this weight loss for at least half a year without any substantial weight fluctuations. The COUD participants' current BMI was $\geq 30$ and they reported no significant weight loss during the past 6 months, in spite of serious attempts to lose weight. Most par- ticipants were female [10/11 (83\%) of FOSD and 11/12 (92\%) of COUD, $\left.\chi^{2}(1)<1\right]$. The groups did not differ in age $(M=43.6$, $\mathrm{SD}=10.5)$, highest lifetime $\mathrm{BMI}(\mathrm{M}=35.4, \mathrm{SD}=5.9)$ and $\mathrm{BMI}$ at the start of the last diet attempt $(M=35.2, S D=5.9)$. None of the participants was in treatment since their last diet attempts, meaning that the weight loss and maintenance of the FOSD group was reached without professional help. At the time of the study, the FOSD had a normal BMI $(\mathrm{M}=24.5, \mathrm{SD}=2.3)$ that was significantly lower than the BMI of the COUD $(M=34.3, \mathrm{SD}=3.8, \mathrm{t}(21)$ $=7.3, \mathrm{p}<0.001)$. The mean weight loss since the last diet attempt in the FOSD was $27.3 \%(\mathrm{SD}=12.7)$ and in the COUD group $3.0 \%$ $(\mathrm{SD}=4.3), \mathrm{t}(21)=6.3, \mathrm{p}<0.001$. FOSD reported stricter dieting on the Restraint Scale [4] $(\mathrm{M}=3.8, \mathrm{SD}=0.7)$ than $\mathrm{COUD}(\mathrm{M}=$ $3.2, \mathrm{SD}=0.6, \mathrm{t}(21)=2.1, \mathrm{p}=0.05)$. On a scale ranging from 1 (never easy) to 4 (always easy), FOSD $(\mathrm{M}=3.6, \mathrm{SD}=0.5)$ reported greater ease to refuse high-calorie tasty foods than COUD $(\mathrm{M}=$ $2.0, \mathrm{SD}=0.5, \mathrm{t}(20)=7.5, \mathrm{p}<0.001)$.

Baseline saliva was collected for 1 min using 3 cotton dental rolls ( 2 rolls between the cheek and lower left and right gum, and 1 roll below the tongue) and about 45 min later saliva was collected during a 1-min exposure to food pictures. Between both saliva measurements the participant was interviewed on weight course and diet history. Then, the participant was exposed to the 9 A-4 format colour pictures of tasty high-calorie foods and salivary response was measured. (S)he was instructed to watch all the pictures while trying to remember them all for a memory test, to prevent any cognitive avoidance, and to give in to the feelings the pictures elicited. The weight of the dental rolls in a small plastic re-sealable bag was registered before and after saliva collection.

The 2 (group: FOSD vs. COUD) $\times 2$ (time: baseline vs. exposure) ANOVA on salivary response found no main effects, F's $<$ 1.1 , but a highly significant interaction, $\mathrm{F}(1,21)=13.96, \mathrm{p}=0.001$. The COUD showed a significant increase in salivation during food exposure $(\mathrm{M}=0.92, \mathrm{SD}=0.61)$ as compared to baseline $(\mathrm{M}=0.71, \mathrm{SD}=0.46, \mathrm{t}(11)=2.4, \mathrm{p}<0.05)$, whereas the FOSD showed a significant decrease in salivary responding during food confrontation $(\mathrm{M}=0.54, \mathrm{SD}=0.17)$ as compared to baseline $(\mathrm{M}=0.73, \mathrm{SD}=0.3, \mathrm{t}(10)=3.2, \mathrm{p}<0.01)$. Both groups remembered an equal number of food pictures $(\mathrm{M}=6.5, \mathrm{SD}=1.0$ for $\mathrm{FOSD}$ and $\mathrm{M}=6.3, \mathrm{SD}=0.8$ for COUD), $\mathrm{F}<1$, making cognitive avoidance during the exposure an unlikely explanation for the difference in salivation response.

FOSD showed decreased cue reactivity (salivation) during confrontation with tempting food cues, whereas COUD showed increased cue reactivity. These data suggest that a dieter who is able to resist high-fat food temptations and keeps dieting if exposed to a 'toxic' environment will experience a decrease in and eventually extinction of automatic urges to eat, which in turn makes it easier to refrain from eating high-fat foods for a longer period of time. It is likely that successful dietary restraint, i.e. a sternly maintained restriction of food intake, reduces salivary responding, whereas an unsuccessful diet, i.e. alternating periods

\section{KARGER}

Fax +41613061234 E-Mail karger@karger.ch www.karger.com
(C) 2010 S. Karger AG, Base

0033-3190/10/0794-0257\$26.00/0

Accessible online at:

www.karger.com/pps 
of dieting and overeating, increases salivary responding. Resisting foods in case of increased cue reactivity is difficult, whereas decreased cue reactivity makes it easier to resist foods. Weight loss maintenance becoming easier over time might be a consequence of extinguished cue reactivity. Thus, the first blow might be half the battle; a successful start of the diet frees the body of its cue reactivity and makes dieting easier and more successful. Cue exposure with response prevention is an effective intervention to extinguish cue reactivity [2] and might therefore be used as a method to maintain weight loss. These data are preliminary; we merely tested cue reactivity to high-fat food cues but not to low-fat food cues in a small cross-sectional sample. We nonetheless found interesting associations between strict and successful dieting with decreased cue reactivity. Future studies should prospectively test whether there is a causal relationship between a decrease in cue reactivity to specifically high-calorie but not low-calorie foods and long-term diet success.

\section{References}

1 Wing RR, Phelan S: Long-term weight loss maintenance. Am J Clin Nutr 2005;82:222S-225S.

$\checkmark 2$ Jansen A: A Learning model of binge eating: cue reactivity and cue exposure. Behav Res Ther 1998;36:257-272.

-3 Power M, Schulkin J: Anticipatory physiological regulation in feeding biology: cephalic phase responses. Appetite 2008;50:194-206.

4 Van Strien T: Dutch Eating Behaviour Questionnaire (manual). Amsterdam, Boom Test Publishers, 2005.
Anita Jansen
Department of Clinical Psychological Science
Faculty of Psychology and Neuroscience
Maastricht University, PO Box 616
NL-6200 MD Maastricht (The Netherlands)
Tel. +31 43388 1910, Fax +31 433884196
E-Mail a.jansen@maastrichtuniversity.nl 